\title{
ANÁLISE DA DECISÃO JUDICIAL SOBRE INFIDELIDADE PARTIDÁRIA (ADIN No 50.81/2015) A PARTIR DA TEORIA ARGUMENTATIVA DE NEIL MACCORMICK
}

\author{
Analysis of the Judicial Decision on Party Infidelity (Adin n $n^{0} 5.081 / 2015$ ) \\ Based on the Argumentative Theory of Neil MacCormick
}

Katarina Karol Brazil de Melo Rocha

José Filomeno de Moraes Filho

Resumo: O presente artigo tem por objetivo analisar a decisão do Supremo Tribunal Federal sobre infidelidade partidária (Ação Direta de Inconstitucionalidade $\mathrm{n}^{\mathrm{O}}$ 5081), a qual assentou que não se deve aplicar a sanção de perda de mandato aos cargos majoritários, tal como constava da Resolução n⿳⼈ㅡㄹ 22.610/2007, do Tribunal Superior Eleitoral, sob pena de violação ao princípio democrático (art. 1ํㅜ parágrafo único da Constituição) e à soberania popular (art. 14, caput, também da Constituição), ambos intrínsecos ao Estado Democrático de Direito. $\mathrm{Na}$ análise será utilizada a teoria de Neil MacCormick, no que tange à argumentação racional e aos processos de justificação utilizados para fundamentar as decisões judiciais.

Palavras-chave: Infidelidade partidária. Supremo Tribunal Federal. Argumentação jurídica. MacCormick.

\begin{abstract}
This article analyzes the decision of the Federal Supreme Court on party infidelity (Direct Action of Unconstitutionality ADI 5081), which established that the sanction of loss of mandate should not apply to politicians in public offices (elected through majority run-off system), as set by Resolution $22610 / 2007$, under penalty of violation of the Democratic Principle (article 1, sole paragraph of the Constitution) and popular sovereignty (article 14, caput, also on the Constitution), both intrinsic to the Democratic Rule of Law. The analysis adopted the theory of Neil MacCormick to examine the rational argumentation and the processes of justification used to support judicial decisions.
\end{abstract}

Keywords: Party infidelity. Federal Supreme Court. Legal arguments. MacCormick.

Artigo recebido em 28 set. 2020 e aprovado em 11 out. 2020. 


\section{Introdução}

A Constituição Federal de 1988 reafirmou a centralidade dos partidos políticos no Estado Democrático de Direito. Todavia, apesar das diversas perspectivas importantes que isso possa representar em termos democráticos, uma delas decorre do peso que se deu ao princípio democrático político (MORAES, 2016). Por isso mesmo, dedicou-lhes um artigo próprio (art.17). Nele, contudo, delega-se aos seus estatutos internos o estabelecimento de normas de disciplina e fidelidade partidária. Por sua vez, o art.55 também não previu, entre as hipóteses de perda de mandato, a infidelidade partidária. A despeito disso, já em 1989, o tema foi levado ao Supremo Tribunal Federal (STF), quando do julgamento do Mandado de Segurança n. ${ }^{\circ}$ 20.927-5/DF (BRASIL, STF, 1989), sob relatoria do ministro Moreira Alves, que confirmou o entendimento da impossibilidade de perda de mandato em função da ausência mesma de previsão constitucional expressa. Em 2004, assim também o entendeu o relator do caso, ministro Gilmar Mendes, no julgamento do Mandado de Segurança 23.405-9/GO (BRASIL, STF, 2004).

A mudança jurisprudencial a respeito da fidelidade partidária se dá em 2007, em consulta, quando o PFL (Partido da Frente Liberal), hoje DEM (Democratas), apresenta ao Tribunal Superior Eleitoral (TSE) a Consulta n. 1.398 (BRASIL, TSE, 2007), que versava sobre a possibilidade de político em exercício de cargo legislativo vir a perdê-lo por infidelidade partidária, ainda que fora das hipóteses para tal constantes no art.55 da Constituição Federal (BRASIL, 1988). O TSE, na Resolução 22.610 (BRASIL, TSE, 2007), estabeleceu, então, hipóteses de perda do mandato, justificando sua perda por infidelidade partidária tanto no sistema proporcional quanto no majoritário. Em função disso, em 2007, chegam ao STF os Mandados de Segurança de no 26.602 - PPS (BRASIL, STF, 2007a), 26.603 - PSDB (BRASIL, STF, 2007b) e 26.604 - DEM (BRASIL, STF, 2007c) contestando a Resolução 22.610 do TSE. Na ocasião, o Supremo decidiu pela constitucionalidade da resolução, sem, entretanto, analisar questões substantivas, ou seja, tendo como pano de fundo apenas o sistema proporcional.

Dentro desse contexto, em 2015, a Procuradoria-Geral da República (PGR) ingressou no STF com a Ação Direta de Inconstitucionalidade (Adin) $\mathrm{n}^{\circ}$ 5081, de 27 de maio (BRASIL, STF, 2015), formulando pedido para declarar-se a inconstitucionalidade da Resolução 22.610/2007, do Tri- 
bunal Superior Eleitoral, quanto ao uso do termo "ou o vice", constante do art. 10, da expressão "e, após 16 (dezesseis) de outubro corrente, quanto a eleitos pelo sistema majoritário", constante do art. 13, e para conferir-se interpretação conforme a Constituição ao termo "suplente", constante do art. 10, com a finalidade de excluir do seu alcance os cargos do sistema majoritário.

Esse artigo tem por objetivo analisar o tema da infidelidade partidária à luz da decisão proferida pelo STF, na Adin n⿳ 5.081, de 27 de maio de 2015, a qual assentou, de uma vez por todas, que a perda do mandato em razão da mudança de partido não se aplica aos candidatos eleitos pelo sistema majoritário, sob pena de violação da soberania popular (Art.1, parágrafo único, e art.14, caput, da Constituição Federal de 1988).

A análise dos votos dos ministros, bem como do acórdão da decisão judicial, será feita com base nas ideias de Neil MacCormick, que se dedicou à construção de uma teoria racional para identificar a validade dos argumentos evocados nas decisões judiciais de casos concretos, sobretudo aqueles difíceis, os chamados hard cases. Assim, divide-se o artigo em três partes. Na primeira delas, tratar-se-á das bases teóricas do autor em questão. $\mathrm{Na}$ segunda, serão apresentados quadros com os argumentos evocados pelos ministros em seus votos. Na última seção, empregar-se-ão os critérios de validade de MacCormick aos votos dos ministros e ao acórdão da decisão.

\section{Breves consideraçõessobre os argumentosinterpretativos à luz da Teoria de Neil MacCormick}

Neil MacCormick (2009) começa por demonstrar a centralidade da razão prática na análise dos fundamentos da argumentação jurídica, razão pela qual se opõe ao ceticismo de Hume, quando ressalta que aderir a princípios gerais é também uma manifestação da razão. MacCormick afirma ainda que se deve estudar "o processo de argumentação como um processo de justificação" . A to contínuo, o autor se debruça sobre o método de justificação dedutivo, segundo o qual "a conclusão está implícita em alguma outra proposição ou proposições, as premissas da argumentação”, e ressalta

\footnotetext{
${ }^{1}$ Em um Estado Democrático de Direito, a justificação das decisões judiciais é componente essencial de sua legitimidade. Isso se encontra estabelecido, inclusive, na Constituição de 1988, que, em seu art. 93, IX, afirma que: "Todos os julgamentos dos órgãos do Poder Judiciário serão públicos, e fundamentadas todas as decisões, sob pena de nulidade [...]" (BRASIL, 1988).
} 
que "a função específica da lógica como ramo do conhecimento consiste em estudar as formas de argumentação válidas" (MACCORMICK, 2009).

$\mathrm{O}$ autor, contudo, alerta para o fato de que as mesmas normas podem resultar "ambíguas ou obscuras em algum contexto questionado ou questionável de litígio", citando ainda Hart, que as vê como uma "trama aberta e vagas em certos sentidos". Daí os limites da argumentação puramente dedutiva. MacCormick, na mesma obra, faz a distinção entre justificação e justiça, e ressalta que a última compreende uma dimensão abstrata, e a primeira, formal. No âmbito formal, para que se faça justiça, os casos semelhantes deverão receber tratamento semelhante; e os diferentes, tratamento diferente. No entanto, o autor enfatiza que o olhar dos juízes deve contemplar mais o futuro do que o passado, já que pode existir conflito entre a observância aos precedentes e a percepção de justiça no caso atual. Assim, entende-se que "as decisões jurídicas devem fazer sentido no mundo e devem também fazer sentido no sistema jurídico”. O desdobramento natural da análise do autor é a consideração sobre os argumentos consequencialistas, que são de caráter avaliatório e, portanto, implicam algum grau de subjetividade (MACCORMICK, 2009).

Nesse sentido, Chamon Junior (2009) afirma que tão somente o argumento de autoridade já não pode sustentar as decisões judiciais, pois na Modernidade impõe-se como dever "lidar racionalmente com a pluralidade ética". Com esse contexto, portanto, hoje se "pressupõe uma justificação não mais sacralizada", ou seja, não apenas "embebida em argumento de autoridade”. Analogamente, Lopes e Benício (2015) assinalam, quando da análise do julgamento do STF da Adin no 1856/2011 - sobre a briga de galos -, que essa decisão exigiu argumentos "capazes de atender os preceitos constitucionais vigentes em um Estado Democrático de Direito, no qual o poder político da autoridade não é condição suficiente da legitimidade de sua atuação".

MacCormick (2009) discorre sobre os critérios de coesão e de coerência para a análise da argumentação. No âmbito da coesão, afirma que o sistema jurídico é um "corpo coeso de normas num sentido estrito", assim, "por mais desejável que uma dada deliberação seja quanto a fundamentos consequencialistas", não há como ser aceita se colidir com uma "norma válida e de caráter obrigatório do sistema". Quanto à coerência, ele a vê como uma reflexão sobre os valores do sistema, compreendendo que a ordenação é a manifestação de princípios mais gerais, indicando dois tipos 
de argumentação coerente: aquela que se dá por analogia e a que implica o apelo a esses mesmos princípios como forma de justificação. Ele vê, ainda, no critério da coerência um elemento limitador do sistema judiciário (MACCORMICK, 2009).

O assunto será retomado e desenvolvido pelo autor em artigo no qual categoriza de forma sintética e sistemática as variedades de argumentação e os critérios de análise das decisões judiciais do ponto de vista argumentativo. Nesse texto, o autor discorre sobre as "razões autoritativas", que são aquelas amparadas pela autoridade da lei. Observa, contudo, que elas, na opinião de muitos autores contemporâneos, são hoje restritivas, e trata-se, segundo o autor, de uma "falácia positivista" acreditar que atualmente essa classe de razões seja o único argumento válido no Direito, pois as decisões, à luz da razão prática, exigem a aplicação da norma em sentido mais geral, uma vez que os juízes devem fundamentar sua argumentação tanto nas razões autoritativas quanto nas substantivas. Aqui, a interpretação - em sentido estrito - e a argumentação se encontram, afinal, "a norma posta em uma fonte autoritativa de direito tem de ser compreendida antes de ser aplicada". Só assim, poder-se-á, consoante o autor, “formar um juízo a fim de resolver a dúvida para decidir a partir do significado que pareça mais adequado ao contexto" (MACCORMICK, 2011, p. 68).

\subsection{Categorias dos argumentos interpretativos de MacCormick (2011)}

Segundo o autor, as três principais categorias de argumentos interpretativos são:

a) linguísticos;

Dividem-se em dois subgrupos e tratam do significado ordinário ou técnico dos termos empregados em um texto jurídico. Ressalte-se que, nesse tipo de argumento, amiúde se fala da intenção do legislador.

b) sistêmicos;

O texto jurídico deve ser visto como parte de um sistema jurídico.

Nessa categoria, destacam-se os:

- argumentos de harmonização contextual - a lei deve ser interpretada segundo as disposições mais próximas dela ou de lei in pari matéria; 
- argumentos de precedente - a interpretação deve estar em conformidade com sua interpretação por outros tribunais, obedecendo-se à hierarquia entre eles;

- argumento de analogia - a disposição pode ser interpretada à luz de disposições análogas, mesmo que se relegue a segundo plano seu significado ordinário para que se assegure a similaridade. Isso pode se dar tanto em relação a uma norma em si mesma quanto em relação a outra interpretação prévia;

- argumento lógico-conceitual - o conceito jurídico geral reconhecido e doutrinário empregado na disposição deve ser levado em conta para que se mantenha o uso consistente da disposição por meio do sistema em seu conjunto ou de algum de seus ramos;

- argumento de princípios gerais - favorece-se a interpretação de acordo com os princípios gerais do Direito aplicável ao assunto de uma disposição legal;

- argumento histórico- a aplicação do Direito ao caso concreto deve estar em consonância com o entendimento historicamente consagrado acerca do assunto.

c) teleológicos/deontológicos;

- teleológicos - partindo de algum tipo de valoração, ocupam-se do que a decisão acarretará (MACCORMICK, 2011). Dialogando com a terminologia de Robert Summers, o autor diz que os argumentos a que classifica como teleológicos são convalidados pelas "razões de objetivo" (goalreasons) (SUMMERS, 1978);

- deontológicos - apelam aos princípios do correto e do incorreto à luz dos princípios maiores, caso em que os princípios são considerados como finais, e não desdobramentos de anterior argumentação teleológica (MACCORMICK, 2011). Aqui a justificação se volta às "razões do correto" (rightnessreasons) (SUMMERS, 1978).

Ainda sobre essas categorias, MacCormick (2011) afirma que a chamada golden rule (regra de ouro), consagrada classicamente, estabelece uma hierarquia, preconizando que se deve começar pelos argumentos linguísticos, passando depois aos sistêmicos e, só então, se necessário, aos teleológicos/deontológicos. Contudo, adverte que a "regra de ouro" pode levar a efeitos conflitantes com a ideia de justiça e com o bem comum. Assim, não se poderia afirmar que os argumentos de natureza teleológica/deon- 
tológica só devem ser evocados se aqueles das duas outras categorias não logram resultados inequívocos. Nos chamados "casos difíceis", podem-se manejar os argumentos de modo a que os teleológicos/deontológicos sejam evocados incialmente para demonstrar interpretações absurdas e mudar uma conclusão prima facie.

Portanto, os argumentos dessas decisões restarão mais sólidos se emanados de "valores", esses que também não são arbitrários, pois remetem à "mesma base valorativa que se reflete na estruturação principiológica de todo o ordenamento" (PEIXOTO; ROESLER; BONAT, 2016, p. 225).

Como se vê, no método proposto por MacCormick (2011), problemas práticos demandam decisões justificáveis. Por conseguinte, a divisão proposta pelo autor visa facilitar a identificação do(s) tipo(s) de argumento apresentado(s) numa decisão para que se possa proceder a uma análise objetiva de sua possível validade diante do sistema jurídico em seu conjunto (razões autoritativas) e do caso concreto (razões substantivas).

\section{Análise dos tipos de argumentos interpretativos invocados na decisão da Adin no ${ }^{\circ}$ 5081/2015}

Aqui, seguir-se-á a categorização de MacCormick (2011) apresentando onze quadros em que os argumentos são classificados como linguísticos, sistêmicos ou teleológicos/deontológicos. Começar-se-á pelo quadro em que constam as razões apresentadas pela PGR para provocar o STF, embora essas, evidentemente, não façam parte da decisão. Em seguida, apresentar-se-ão àqueles com os respectivos argumentos evocados por cada um dos ministros, iniciando-se pelos argumentos constantes no voto do ministro relator e seguindo-se a sequência mesma dos votos dos ministros no texto da decisão do STF. No último quadro, classificar-se-ão os argumentos constantes na ementa da decisão. Cabe ressaltar que os textos não representam a transcrição literal dos votos, pois, sempre que necessário à clareza são feitas adaptações (paráfrases e sínteses). 


\section{QUADRO 1 - Argumentos da Procuradoria-Geral da República}

\begin{tabular}{|c|c|}
\hline $\begin{array}{l}\text { Argumento } \\
\text { linguístico }\end{array}$ & $\begin{array}{l}\text { Os termos “suplente" e "ou o vice", constantes no art. } 10 \text { da Resolução } \\
\text { no } 22.610 / 2007 \text { e o trecho "e, após } 16 \text { (dezesseis) de outubro corrente, } \\
\text { quanto a eleitos pelo sistema majoritário", inscrito no art. } 13 \text { da mesma } \\
\text { Resolução, violam o sistema eleitoral e o estatuto constitucional dos } \\
\text { congressistas, especialmente os arts. 14, caput; 46, caput; 55, caput; e } \\
\text { os parágrafos do art. } 77 \text {, todos da Constituição. }\end{array}$ \\
\hline $\begin{array}{l}\text { nento } \\
\text { ico }\end{array}$ & $\begin{array}{l}\text { As Ações Diretas de Inconstitucionalidade (ADIs) 3.999/DF e } \\
\text { 4.086/DF proclamaram a constitucionalidade formal da Resolução no } \\
\text { 22.610/2007, sem analisar questões substantivas. No mérito, entende } \\
\text { que os Mandados de Segurança } \mathrm{n}^{\circ} \text { 26.602, } \mathrm{n}^{\circ} 26.603 \text { e } \mathrm{n}^{\mathrm{o}} 26.604 \\
\text { analisaram a perda do mandato por desfiliação exclusivamente para } \\
\text { cargos eletivos do sistema proporcional, tendo se assinalado que o } \\
\text { propósito da perda é a retomada do mandato pelo partido lesado. } \\
\text { A Corte teria articulado um princípio de pertencimento do cargo } \\
\text { eletivo de deputado ao partido, que resultaria (i) da intermediação } \\
\text { necessária da legenda partidária para a disputa eleitoral e (ii) da natureza } \\
\text { do sistema eleitoral proporcional, em que o eleitor vota no partido } \\
\text { mais do que no candidato. } \\
\text { A PGR sustenta a inaplicabilidade da regra da fidelidade partidária ao } \\
\text { sistema majoritário. Isso porque o vínculo do mandato com o partido } \\
\text { no sistema majoritário é mais tênue, pois não se orienta pela mesma } \\
\text { lógica do sistema proporcional. }\end{array}$ \\
\hline $\begin{array}{l}\text { Argun } \\
\text { teleolc }\end{array}$ & $\begin{array}{l}\text { A perda de mandato no sistema majoritário não necessariamente } \\
\text { beneficiaria o partido, pois as chapas em eleições majoritárias são } \\
\text { formadas, em diversos casos, por candidatos de diferentes agremiações } \\
\text { partidárias. }\end{array}$ \\
\hline $\begin{array}{l}\text { Argumento } \\
\text { deontológico }\end{array}$ & $\begin{array}{l}\text { A aplicação da fidelidade partidária para o sistema majoritário ofende a } \\
\text { soberania popular (art. 14, caput, CF). }\end{array}$ \\
\hline $\begin{array}{l}\text { Argumento } \\
\text { sistêmico }\end{array}$ & $\begin{array}{l}\text { Ofende ainda as características constitucionais do sistema majoritário } \\
\text { (arts. 46, caput, e } 77, \mathrm{CF} \text { ) e as hipóteses de perda de mandato } \\
\text { parlamentar (art. 55, CF). }\end{array}$ \\
\hline
\end{tabular}

Fonte: Elaboração própria.

\section{QUADRO 2 - Argumentos do ministro relator Luís Roberto Barroso}

\begin{tabular}{|c|c|}
\hline $\begin{array}{l}\text { Argumento } \\
\text { sistêmico }\end{array}$ & $\begin{array}{l}\text { As decisões nos Mandados de Segurança } n^{\circ} \text { 26.602, no } 26.603 \text { e } \\
\mathrm{n}^{-} 26.604 \text { tiveram como pano de fundo o sistema proporcional, no } \\
\text { qual, por sua ênfase nos votos obtidos pelos partidos, a fidelidade } \\
\text { partidária é importante para garantir que as opções políticas feitas pelo } \\
\text { eleitor no momento da eleição sejam minimamente preservadas. Daí } \\
\text { a legitimidade de se decretar a perda do mandato do candidato que } \\
\text { abandona a legenda pela qual se elegeu. }\end{array}$ \\
\hline
\end{tabular}




\begin{tabular}{|c|c|}
\hline $\begin{array}{l}\text { Argumento } \\
\text { sistêmico }\end{array}$ & $\begin{array}{l}\text { O sistema majoritário tem lógica e dinâmica diversas da do sistema } \\
\text { proporcional. Suas características do sistema majoritário, com ênfase } \\
\text { na figura do candidato, fazem com que a perda do mandato, no caso de } \\
\text { mudança de partido, frustre a vontade do eleitor e vulnere a soberania } \\
\text { popular (CF, art. 1, par. ún. e art. 14, caput). }\end{array}$ \\
\hline $\begin{array}{l}\text { Argumento } \\
\text { sistêmico }\end{array}$ & $\begin{array}{l}\text { a) não há, na Constituição de } 1988 \text {, qualquer previsão expressa da } \\
\text { "regra da fidelidade partidária". A Emenda Constitucional no } 1 \text { de } \\
1969 \text { previa a infidelidade partidária como hipótese explícita de perda } \\
\text { do mandato de deputados e senadores (art. 35, V). A Carta de } 1988 \text {, } \\
\text { contudo, não reproduziu a sanção, que de resto já havia sido suprimida } \\
\text { do texto anterior pelo art. } 8^{\circ} \text { da Emenda Constitucional no } 25 / 1985 \text {. O } \\
\text { STF tradicionalmente considera que o artigo } 55 \text { contém rol taxativo de } \\
\text { hipóteses de perda do mandato parlamentar, e, como se sabe, nele não } \\
\text { se encontra a troca de partido por parlamentar. } \\
\text { b) no sistema proporcional há fundamento constitucional consistente } \\
\text { para a sua construção jurisprudencial; porém, no sistema majoritário } \\
\text { não há. É absolutamente incoerente que determinado parlamentar seja } \\
\text { eleito em razão dos votos dados à legenda ou a um correligionário } \\
\text { com votação extraordinária e, durante seu mandato (muitas vezes logo } \\
\text { no seu início), migre para outro partido que em nada colaborou para } \\
\text { a sua eleição. A infidelidade partidária, principalmente na proporção } \\
\text { assumida no Brasil, representava completo desvirtuamento do sistema } \\
\text { proporcional, da democracia representativa e da soberania popular. } \\
\text { c) o mesmo não ocorre no sistema majoritário. Nesse, como a } \\
\text { fórmula eleitoral é a regra da maioria e não a do quociente eleitoral, o } \\
\text { candidato eleito será o mais bem votado. Como serão desconsiderados } \\
\text { os votos dados aos candidatos derrotados, não se coloca fenômeno } \\
\text { da transferência de votos. Assim, no sistema majoritário a "regra da } \\
\text { fidelidade partidária" não consiste em medida necessária à preservação } \\
\text { da vontade do eleitor, como ocorre no sistema proporcional, e, } \\
\text { portanto, não se trata de corolário natural do princípio da soberania } \\
\text { popular (arts. 1o, parágrafo único e } 14 \text {, caput, da Constituição). }\end{array}$ \\
\hline $\begin{array}{l}\text { Argumento } \\
\text { deontológico }\end{array}$ & $\begin{array}{l}\text { No sistema majoritário atualmente aplicado no Brasil, a imposição de } \\
\text { perda do mandato por infidelidade partidária se antagoniza como a } \\
\text { soberania popular, que, como se sabe, integra o núcleo essencial do } \\
\text { princípio democrático. }\end{array}$ \\
\hline
\end{tabular}




\begin{tabular}{|c|c|}
\hline $\begin{array}{l}\text { Argumento } \\
\text { teleológico }\end{array}$ & $\begin{array}{l}\text { Ademais, se o objetivo da fidelidade partidária é devolver o mandato } \\
\text { ao partido político que o conquistou com o voto, a aplicação da perda } \\
\text { de mandato ainda menos se justifica para o cargo de Chefe do Poder } \\
\text { Executivo. Isso porque não há obrigatoriedade de que titular e vice } \\
\text { sejam do mesmo partido. Aliás, não é raro que, por conta das coligações } \\
\text { partidárias, os componentes da chapa sejam de distintas agremiações } \\
\text { partidárias. Nesses casos, a perda de mandato favoreceria candidato } \\
\text { e partido que não receberam votos, em detrimento de candidato que } \\
\text { obteve, no mínimo, a maioria absoluta dos votos colhidos no pleito. } \\
\text { Assim, a substituição de candidato respaldado por ampla legitimidade } \\
\text { democrática por vice carente de votos, claramente se descola do } \\
\text { princípio da soberania popular e, como regra, não protegerá o partido } \\
\text { prejudicado com a migração do Chefe do Executivo eleito pelo povo. }\end{array}$ \\
\hline $\begin{array}{l}\text { Argumento } \\
\text { sistêmico }\end{array}$ & $\begin{array}{l}\text { Com efeito, o vínculo entre partido e mandato é muito mais tênue no } \\
\text { sistema majoritário do que no proporcional, não apenas pela inexistência } \\
\text { de transferência de votos, mas pela circunstância de a votação se centrar } \\
\text { muito mais na figura do candidato do que na do partido. Com efeito, } \\
\text { nos pleitos majoritários os eleitores votam em candidatos e não em } \\
\text { partidos, o que é reconhecido pela própria Constituição Federal ao } \\
\text { prever, em seu art. } 77, \int 2^{\circ} \text {, que "será considerado eleito Presidente } \\
\text { o candidato que, registrado por partido político, obtiver a maioria } \\
\text { absoluta de votos (...)". }\end{array}$ \\
\hline $\begin{array}{l}\text { Argumento } \\
\text { sistêmico }\end{array}$ & $\begin{array}{l}\text { Não parece certo afirmar que o constituinte de } 1988 \text { haja instituído } \\
\text { uma "democracia de partidos". Com efeito, o art. 1ํ, parágrafo único } \\
\text { da Constituição é inequívoco ao estabelecer a soberania popular } \\
\text { como fonte última de legitimação de todos os poderes públicos, ao } \\
\text { proclamar que "todo o poder emana do povo, que o exerce por meio de } \\
\text { representantes eleitos ou diretamente, nos termos desta Constituição". }\end{array}$ \\
\hline $\begin{array}{l}\text { Argumento } \\
\text { teleológico }\end{array}$ & $\begin{array}{l}\text { Se o objetivo perseguido é o aperfeiçoamento da democracia } \\
\text { representativa e do modelo eleitoral brasileiro, a extensão da fidelidade } \\
\text { partidária ao sistema majoritário subverte esse propósito, agravando o } \\
\text { problema sob o pretexto de saná-lo. }\end{array}$ \\
\hline $\begin{array}{l}\text { Argumento } \\
\text { sistêmico }\end{array}$ & $\begin{array}{l}\text { Em suma, entendo que os arts. } 10 \text { e } 13 \text { da Resolução n⿳0 } 22.610 / 2007 \text {, ao } \\
\text { igualarem os sistemas proporcional e majoritário para fins de fidelidade } \\
\text { partidária, violam as características essenciais dos sistemas eleitorais } \\
\text { dispostos na Constituição, extrapolam indevidamente os fundamentos } \\
\text { das decisões proferidas por esta Corte nos Mandados de Segurança } \\
n^{-} 26.602 \text {, no } 26.603 \text { e } n^{\circ} 26.604 \text { e, sobretudo, afrontam a soberania } \\
\text { popular. }\end{array}$ \\
\hline
\end{tabular}




\begin{tabular}{|l|l|}
\hline $\begin{array}{l}\text { Argumento } \\
\text { linguístico }\end{array}$ & $\begin{array}{l}\text { Diante do exposto, julgo procedente o pedido para declarar } \\
\text { inconstitucional o termo “ou vice", constante do art. 10 da Resolução } \\
\mathrm{n}^{\mathrm{O}} 22.610 / 2007, \text { e a expressão "e, após 16 (dezesseis) de outubro } \\
\text { corrente, quanto a eleitos pelo sistema majoritário", constante do art. } \\
\text { 13. Por fim, confiro interpretação conforme a Constituição ao termo } \\
\text { "suplente", constante do art. 10, com a finalidade de excluir do seu } \\
\text { alcance os cargos do sistema majoritário. }\end{array}$ \\
\hline $\begin{array}{l}\text { Argumento } \\
\text { sistêmico }\end{array}$ & $\begin{array}{l}\text { A tese que embasa o meu voto é a seguinte: "A perda do mandato em } \\
\text { razão de mudança de partido não se aplica aos candidatos eleitos pelo } \\
\text { sistema majoritário, sob pena de violação da soberania popular e das } \\
\text { escolhas feitas pelo eleitor". }\end{array}$ \\
\hline
\end{tabular}

Fonte: Elaboração própria.

\section{QUADRO 3 - Argumentos do ministro Teori Zavascki}

\begin{tabular}{|l|l|}
\hline $\begin{array}{l}\text { Argumento } \\
\text { sistêmico }\end{array}$ & $\begin{array}{l}\text { A disciplina e a fidelidade partidária estão no art. 17, } \mathbb{1} 1 \text {, e isso } \\
\text { tem que gerar alguma consequência. Se é certo que, no campo dos } \\
\text { cargos eletivos obtidos em votação proporcional, se pode retirar da } \\
\text { Constituição a consequência da perda do mandato, pelas razões } \\
\text { indicadas pelo ministro relator, essa mesma lógica não parece tão clara, } \\
\text { tão evidente ou tão natural em se tratando de cargo obtido por eleição } \\
\text { majoritária. }\end{array}$ \\
\hline $\begin{array}{l}\text { Argumento } \\
\text { teleológico }\end{array}$ & $\begin{array}{l}\text { Seria uma consequência que não decorre da Constituição e, pelo menos } \\
\text { em relação ao sistema eleitoral que hoje nós temos, seria absolutamente } \\
\text { incompatível com esse sistema que, havendo mudança de partido, a } \\
\text { consequência seria essa tão drástica perda do cargo. }\end{array}$ \\
\hline
\end{tabular}

Fonte: Elaboração própria.

\section{QUADRO 4 - Argumentos do ministro Dias Toffoli}

\begin{tabular}{|l|l|}
\hline $\begin{array}{l}\text { Argumen to } \\
\text { sistêmico }\end{array}$ & $\begin{array}{l}\text { Como explicita Maurizio Cotta (2010), a escolha do sistema partidário } \\
\text { não se resume à forma de decidir quais são os eleitos; a escolha entre o } \\
\text { sistema de listas abertas e listas fechadas significa também decidir qual } \\
\text { o aspecto da representação que se quer ressaltar. }\end{array}$ \\
\hline $\begin{array}{l}\text { Argumen to } \\
\text { sistêmico }\end{array}$ & $\begin{array}{l}\text { Desse modo, embora a filiação partidária seja condição de elegibilidade } \\
\left.\text { (art. } 14, \int 3 \text { o }, \mathrm{V}, \mathrm{CF} / 88\right) \text {, não se admitindo candidaturas avulsas, o voto } \\
\text { só na legenda partidária é apenas uma faculdade do eleitor (art. 176 do } \\
\text { Código Eleitoral), opção exercida por uma pequena minoria de eleitores. } \\
\text { Conquanto se faculte a possibilidade do voto de legenda, a verdade é } \\
\text { que o voto do eleitor brasileiro, mesmo nas eleições proporcionais, em } \\
\text { geral, se dá em favor de determinado candidato. }\end{array}$ \\
\hline
\end{tabular}




\begin{tabular}{|l|l|}
\hline $\begin{array}{l}\text { Argumento } \\
\text { teleológico }\end{array}$ & $\begin{array}{l}\text { Acompanho o voto do relator, também entendendo que, no que diz } \\
\text { respeito aos cargos majoritários, não há possibilidade de o partido } \\
\text { político requerer esse cargo em razão de uma infidelidade. Vamos, por } \\
\text { hipótese, imaginar que a presidenta Dilma Rousseff se desfiliasse, hoje, } \\
\text { do PT e fosse para outro partido. O PT iria pedir o cargo majoritário } \\
\text { para quem? }\end{array}$ \\
\hline
\end{tabular}

Fonte: Elaboração própria.

\section{QUADRO 5 - Argumentos da ministra Cármen Lúcia}

\begin{tabular}{|l|l|}
\hline $\begin{array}{l}\text { Argumento } \\
\text { sistêmico }\end{array}$ & $\begin{array}{l}\text { Tenho como fundamentada a distinção dos dois casos (proporcional } \\
\text { e majoritário), exatamente, porque, num caso, escolhe-se o partido, e, } \\
\text { então, é que se leva à conclusão sobre os eleitos, e, no caso da majoritária, } \\
\text { como foi muito bem exposto aqui por todos que me antecederam, o } \\
\text { que se elege é uma pessoa que está vinculada a um cargo, em face da } \\
\text { impossibilidade de haver candidaturas avulsas. }\end{array}$ \\
\hline
\end{tabular}

Fonte: Elaboração própria.

\section{QUADRO 6 - Argumentos do ministro Gilmar Mendes}

\begin{tabular}{|l|l|}
\hline $\begin{array}{l}\text { Argumen to } \\
\text { sistêmico }\end{array}$ & $\begin{array}{l}\text { Só queria lembrar que, no TSE, recentemente, não faz muito tempo, } \\
\text { nós tivemos um caso em que se vindicava o mandato de um senador e } \\
\text { se colocava exatamente a questão que o ministro Toffoli apontou: os } \\
\text { suplentes eram de outros partidos e eles também tinham participado } \\
\text { dessa atividade migratória, quando viram a possibilidade de abocanhar } \\
\text { o mandato deste suposto trânsfuga, então, voltaram à agremiação de } \\
\text { origem. } \\
\text { Portanto, tudo isso acaba sendo muito dinâmico no processo, e nós } \\
\text { então assentamos que: "3. Considerando-se que os suplentes do } \\
\text { mandato em disputa foram eleitos por partido político diverso, não } \\
\text { será possível à legenda requerente recuperar a vaga ocupada pelo } \\
\text { parlamentar trânsfuga". }\end{array}$ \\
\hline $\begin{array}{l}\text { Argumento } \\
\text { sistêmico }\end{array}$ & $\begin{array}{l}\text { Então, deixamos isso assente, fazendo um distinguishing em relação à } \\
\text { situação que se colocava, tal como apontou o ministro Toffoli. }\end{array}$ \\
\hline
\end{tabular}

Fonte: Elaboração própria.

\section{QUADRO 7 - Argumentos do ministro Marco Aurélio}

\begin{tabular}{|l|l|}
\hline $\begin{array}{l}\text { Argumen to } \\
\text { sistêmico }\end{array}$ & $\begin{array}{l}\text { O que nos vem do Código Eleitoral? Uma disciplina toda própria, mas } \\
\text { ligada apenas à espécie proporcional, não alcançando, como estão nos } \\
\text { artigos 106, 107, } 109 \text { do Código Eleitoral, as eleições majoritárias. }\end{array}$ \\
\hline $\begin{array}{l}\text { Argumen to } \\
\text { linguístico }\end{array}$ & $\begin{array}{l}\text { (...) Vem-nos, presidente, sob o ângulo da fidelidade, da Lei dos } \\
\text { Partidos Políticos - de no } 9.096 / 95-\text {, regra que sinaliza a distinção } \\
\text { entre eleições proporcionais e majoritárias. Que regra é essa? Que há } \\
\text { perda pelo parlamentar - e o vocábulo deve ser entendido de forma } \\
\text { estrita, não alcançando o senador -, no caso de infidelidade partidária. }\end{array}$ \\
\hline
\end{tabular}




\begin{tabular}{|l|l|}
\hline $\begin{array}{l}\text { Argumento } \\
\text { sistêmico }\end{array}$ & $\begin{array}{l}(. . .) \text { Não podemos afirmar que as eleições proporcionais e as } \\
\text { majoritárias têm a mesma regência. O eleitor, quando elege o senador } \\
\text { da República, elege o prefeito, elege o governador, elege o presidente, } \\
\text { considera, substancialmente, o perfil do candidato. E não se chega à } \\
\text { conclusão sobre a vitória, no certame eleitoral, tendo em conta os votos } \\
\text { atribuídos à legenda que tenha capitaneado a eleição. }\end{array}$ \\
\hline
\end{tabular}

Fonte: Elaboração própria.

\section{QUADRO 8 - Argumentos do ministro Celso de Melo}

\begin{tabular}{|l|l|}
\hline $\begin{array}{l}\text { Argumento } \\
\text { sistêmico }\end{array}$ & $\begin{array}{l}\text { A discussão suscitada nesta sede de controle normativo abstrato } \\
\text { envolve aspectos que, bem destacados neste julgamento, autorizam o } \\
\text { "distinguishing" a que procedeu ao eminente relator, especialmente no } \\
\text { ponto em que Sua Excelência corretamente assinalou que o sistema } \\
\text { majoritário possui "lógica e dinâmica diversas" daquelas que se revelam } \\
\text { inerentes "ao sistema proporcional". } \\
\text { Ao acolher a "substanciosa fundamentação" em que se apoia o } \\
\text { eminente relator, também julgo procedente o pedido formulado nesta } \\
\text { ação direta e registro a minha concordância com a tese segundo a qual } \\
\text { "A perda do mandato em razão da mudança de partido não se aplica } \\
\text { aos candidatos eleitos pelo sistema majoritário, sob pena de violação da } \\
\text { soberania popular e das escolhas feitas pelo eleitor". }\end{array}$ \\
\hline
\end{tabular}

Fonte: Elaboração própria.

\section{QUADRO 9 - Argumentos do ministro Luiz Fux}

\begin{tabular}{|l|l|}
\hline $\begin{array}{l}\text { Argumen to } \\
\text { sistêmico }\end{array}$ & $\begin{array}{l}\text { No sistema proporcional, dificilmente um candidato obtém número de } \\
\text { votos equivalente ou superior ao quociente eleitoral, i.e., número suficiente } \\
\text { para garantir, por si, sua eleição. A maioria dos candidatos eleitos só } \\
\text { conquista a vaga pela sistemática de redistribuição de votos no interior } \\
\text { do partido. O eleitor, quando do exercício do iussuffragii,vota não apenas } \\
\text { no candidato, mas também, como decorrência de nossa regra de decisão, } \\
\text { no partido político. Justamente por essa razão, o dever de observância à } \\
\text { soberania popular passa pela imposição da regra defidelidade partidária. } \\
\text { Essa lógica, todavia, não é aplicável ao sistema majoritário, pois nele } \\
\text { existe maior protagonismo do candidato, na medida em que o eleitor } \\
\text { procede à escolha do seu voto através de qualidade políticas subjetivas } \\
\text { do postulante (BONAVIDES, 2009, p. 266). } \\
\text { Concluo que "a extensão da regra da fidelidade partidária nos pleitos } \\
\text { majoritários importa inequívoca vulneração da soberania popular". }\end{array}$ \\
\hline
\end{tabular}

Fonte: Elaboração própria. 


\section{QUADRO 10 - Argumentos do ministro Ricardo Lewandowisk}

\begin{tabular}{|l|l|}
\hline $\begin{array}{l}\text { Argumen to } \\
\text { sistêmico }\end{array}$ & $\begin{array}{l}\text { Levar às últimas consequências a conclusão da Corte aplicada ao } \\
\text { sistema proporcional levaria a criarmos uma nova hipótese de perda de } \\
\text { mandato não prevista no art. } 55 \mathrm{da} C F / 88 .\end{array}$ \\
\hline $\begin{array}{l}\text { Argumen to } \\
\text { teleológico }\end{array}$ & $\begin{array}{l}\text { E, além disso, configuraria uma ofensa a uma das características mais } \\
\text { expressivas do sistema majoritário: a imediatidade da relação entre os } \\
\text { eleitores e o eleito, coisa que não ocorre no sistema proporcional, no } \\
\text { qual a tônica é a mediação desta relação entre eleitores e eleito por um } \\
\text { partido político. }\end{array}$ \\
\hline
\end{tabular}

Fonte: Elaboração própria.

\section{QUADRO 11 - Acórdão}

\begin{tabular}{|l|l|}
\hline $\begin{array}{l}\text { Argumento } \\
\text { linguístico }\end{array}$ & $\begin{array}{l}\text { O STF julgou por unanimidade de votos procedente o pedido } \\
\text { formulado para declarar a inconstitucionalidade, quanto à Resolução } \\
22.610 / 2007, \text { do Tribunal Superior Eleitoral, do termo "ou o vice", } \\
\text { constante do art. 10; da expressão "e, após 16 (dezesseis) de outubro } \\
\text { corrente, quanto a eleitos pelo sistema majoritário", constante do art. } \\
\text { 13, e para conferir interpretação conforme a Constituição ao termo } \\
\text { "suplente", constante do art. 10, com a finalidade de excluir do seu } \\
\text { alcance os cargos do sistema majoritário. }\end{array}$ \\
\hline $\begin{array}{l}\text { Argumento } \\
\text { deontológico }\end{array}$ & $\begin{array}{l}\text { Fixada a tese com o seguinte teor: "A perda do mandato em razão da } \\
\text { mudança de partido não se aplica aos candidatos eleitos pelo sistema } \\
\text { majoritário, sob pena de violação da soberania popular e das escolhas } \\
\text { feitas pelo eleitor", nos termos do voto do relator. }\end{array}$ \\
\hline
\end{tabular}

Fonte: Elaboração própria.

\section{Aplicação dos requisitos de Maccormick}

Como se viu na introdução, MacCormick (2011) desenvolve a ideia de consistência e coerência na análise da argumentação. Esses requisitos são somados à necessidade da universabilidade dos argumentos (MARTINS; ROESLER; JESUS, 2011). E aqui, antes de aplicá-los à decisão do STF sobre a Adin no 5081/2015 - sobre a perda de mandato para os casos de infidelidade partidária daqueles eleitos no sistema majoritário -, cabe discorrer brevemente sobre esses requisitos.

$\mathrm{O}$ requisito da universabilidade preconiza que os argumentos empregados na decisão sejam também aplicados a casos similares. Perceba-se que MacCormick (2008) retoma a ideia de que o juiz deve olhar mais para o futuro que para os precedentes, já que sua decisão gerará, ela mesma, precedência para casos, a partir de então. 
Por sua vez, o requisito da consistência exige que uma decisão não pode contradizer seus fundamentos, isto é, não pode haver contradição entre uma ou mais proposições (MARTINS; ROESLER; JESUS, 2011). Ou seja, os argumentos apresentados na justificativa não podem colidir com a própria decisão. Vale ressaltar que MacCormick (2011), por meio desse requisito, reafirma, como se viu na introdução deste trabalho, a importância específica da lógica no estudo das formas de argumentação válidas.

Por último, o requisito da coerência implica que a coesão lógica dos argumentos apresentados na decisão seja cotejada com o sistema jurídico em sua totalidade. Mais uma vez, o autor retoma a centralidade do uso da razão prática na decisão de forma a que esteja ela em conformidade com a ordem jurídica. Cabe perceber, ainda, que deve haver a compatibilidade de valores (axiológica, portanto) entre as normas à vista de um princípio comum (MARTINS; ROESLER; JESUS, 2011).

Como se trata de decisão unânime, analisar-se-ão os argumentos usados no voto de cada ministro apenas quando acrescentem argumentos ao voto do ministro relator, haja vista que alguns ministros apenas exaltaram a qualidade dos argumentos do voto do relator e declaram votar em conformidade com ele.

a) para a verificação do critério de universabilidade, serão analisados argumentos os votos de cada ministro e, depois, do acórdão;

b) para a verificação da consistência, serão analisados os votos de cada ministro, comparando-os, se for o caso, e também o acórdão;

c) na análise da coerência, serão analisados os argumentos do acórdão.

\subsection{Da universabilidade}

Em seu conjunto, os votos dos ministros e do acórdão cumprem o requisito da universabilidade, pois podem ser aplicados a casos semelhantes, uma vez que foi feito, como destacou o ministro Gilmar Mendes, o distinguishing - sobre o qual se falará na análise do requisito de coerência entre os sistemas proporcional e majoritário. Com efeito, a decisão na Adin $\mathrm{n}^{\circ} 5081$ (BRASIL, STF, 2015) atende a esse requisito, valendo sua observância a qualquer outra situação em que esteja em jogo a perda de mandato por infidelidade partidária, no âmbito dos cargos do sistema majoritário. 


\subsection{Da consistência}

Ao menos em uma parte, o voto do ministro relator não satisfaz o critério, pois, em seus argumentos, ele indica que "não há, na Constituição de 1988, qualquer previsão expressa da "regra da fidelidade partidária", e diz ainda que "o STF tradicionalmente considera que o artigo 55 contém rol taxativo de hipóteses de perda do mandato parlamentar, e, como se sabe, nele não se encontra a troca de partido por parlamentar". O voto dá, ainda, maior ênfase a esse aspecto, quando relembra que a "Emenda Constitucional de 1969 previa a infidelidade partidária como hipótese explícita de perda do mandato de deputados e senadores (art. 35, V)", mas que ela, porém, não foi recepcionada pela Constitucional de $1988^{2}$.

Portanto, ao alegar, mais adiante, que o "No sistema proporcional há fundamento constitucional consistente para a sua construção jurisprudencial; porém, no sistema majoritário não há", o voto contradiz a norma de início evocada. Além disso, o ministro relator não explica como a jurisprudência poderia ser construída uma vez que contradiz a norma evocada ${ }^{3}$. $\mathrm{Na}$ verdade, ele apenas reafirma a decisão de 2007 em relação ao julgamento dos Mandados de Segurança oㅡ 26.602, no 26.603 e no 26.604. Nesse sentido, Salgado (2015, p.153-154), ao analisar a própria decisão de 2007, já alertava que "a liberdade para o exercício do mandato eletivo é princípio constitucional estruturante" e que "na falta de suporte constitucional para a 'extração' da fidelidade partidária, a construção jurisprudencial é incoerente com as decisões constituintes". Por isso mesmo, Rubinger-Betti e Roesler (2017, p.142) afirmam que "uma decisão inconsistente é extremamente frágil do ponto de vista argumentativo" e ainda consideram que "a hierarquia entre as normas também serve como exemplo do requisito da consistência".

Do mesmo problema padece o voto do ministro Lewandowisk, pois ele afirma que "levar às últimas consequências a conclusão da Corte aplicada ao sistema proporcional levaria a criarmos uma nova hipótese de

2 "O instituto da fidelidade partidária foi introduzido no ordenamento jurídico brasileiro pela legislação constitucional de 1969 e regulamentado pela Lei 5.682/71. Mas, perdeu sua eficácia com a Emenda Constitucional 25/85. No processo de elaboração da Constituição da República Federativa do Brasil de 1988, o debate sobre o instituto da fidelidade partidária voltou a ser objeto de discussão política e jurídica” (MEZZAROBA, 2013).

${ }^{3}$ Nesse sentido, Leite (2013), ao comentar a mudança de entendimento do STF sobre infidelidade partidária de 2007, comenta que os argumentos utilizados na decisão "foram os mais variados, os quais, por vezes, versam sobre sistemas jurídicos diversos, e que em muitos tons são incompatíveis com a realidade brasileira".

Resenha Eleitoral (Florianópolis), v. 24, n. 1, p. 33-56, 2020 
perda de mandato não prevista no art. 55 da Constituição", sem atentar para o fato de que a conclusão do STF sobre o próprio sistema proporcional já contradizia o "rol taxativo" das hipóteses de perda de mandato do art. 55, uma vez que o artigo não coloca entre elas a infidelidade partidária.

O acórdão, por sua vez, obedece ao critério em questão, pois não reproduz o argumento do ministro relator no que diz respeito à ausência de previsão expressa na Constituição de 1988 da infidelidade partidária e às razões possíveis - rol taxativo, segundo o texto do próprio ministro relator - para a perda de mandato no artigo 55. O acórdão limita-se, pois, a afirmar que "A perda do mandato em razão da mudança de partido não se aplica aos candidatos eleitos pelo sistema majoritário, sob pena de violação da soberania popular e das escolhas feitas pelo eleitor". Ou seja, o argumento é tão somente arts.1ำ parágrafo único, e 14, caput, da Constituição.

\subsection{Da coerência}

Todos os votos e o próprio acórdão se mostram coerentes, pois que em conformidade com o argumento de que a extensão da perda de mandato ao sistema majoritário feriria o princípio da soberania popular, que é um valor intrínseco à Constituição de 1988. Isso inclusive dá vezo a que o voto do ministro Gilmar Mendes (quadro 6) traga a noção de distinguishing em alusão ao caso, então recente, "em que se vindicava o mandato de um senador e se colocava exatamente a questão que o ministro Toffoli apontou: os suplentes eram de outros partidos" quando se assentou que "3. Considerando-se que os suplentes do mandato em disputa foram eleitos por partido político diverso, não será possível à legenda requerente recuperar a vaga ocupada pelo parlamentar trânsfuga.” (p. 64 da Decisão).

Vale lembrar que o distinguishing ${ }^{4}$ ocorre quando a fundamentação da decisão pelo magistrado remeter a um caso precedente que possui im-

\footnotetext{
${ }^{4} \mathrm{O}$ julgador ao avaliar o caso concreto e os argumentos apresentados pelas partes, precisará fundamentar sua decisão, seja acolhendo ou afastando o precedente (quando precisará aplicar o distinguishing), nos termos do artigo 489 \ 1ำ VI, do Código de Processo Civil: Art. 489. São elementos essenciais da sentença: "Art. 489. São elementos essenciais da sentença: I - o relatório, que conterá os nomes das partes, a identificação do caso, com a suma do pedido e da contestação, e o registro das principais ocorrências havidas no andamento do processo; II - os fundamentos, em que o juiz analisará as questões de fato e de direito; III - o dispositivo, em que o juiz resolverá as questões principais que as partes lhe submeterem. $\int 1^{\varrho}$ Não se considera fundamentada qualquer decisão judicial, seja ela interlocutória, sentença ou acórdão, que: I - se limitar à indicação, à reprodução ou à paráfrase de ato normativo, sem explicar sua relação com a causa ou a questão decidida; 
plicações diretas no caso sob julgamento. Sempre que isso ocorrer, deve-se aplicar a técnica do distinguishing para evidenciar as razões pelas quais determinado precedente não pode mais ser aplicado, sob pena de se proferir uma decisão judicial injusta, ou, em última análise, que contrarie a sistemática constitucional. Sobre esse tema, Marinoni (2013, p. 325) elucida que "o distinguishing expressa a distinção entre casos para o efeito de se subordinar, ou não, o caso sob julgamento a um precedente."

\section{Considerações finais}

A Ação Direta de Inconstitucionalidade n 5.081 (BRASIL, STF, 2015), na qual se estabeleceu a inaplicabilidade da sanção de perda do mandato eletivo - disciplinada por meio da Resolução do Tribunal Superior Eleitoral $\mathrm{n}^{\circ}$ 22.610/2007 (BRASIL, TSE, 2007) - para o caso de eleitos pelo sistema majoritário constituiu mais um capítulo da tramitação do tema da infidelidade partidária no Supremo Tribunal Federal. Assim, o STF teve que avaliar os impactos dessa sanção no caso de eleitos não com base na regra do quociente eleitoral, mas sim com base na regra da maioria, fórmula que embasa as eleições para os representantes no sistema majoritário. Na ocasião, ficou assentado, por unanimidade, que a perda do mandato por infidelidade partidária não atinge o sistema majoritário, mas tão somente o proporcional.

Para a análise em profundidade dos argumentos utilizados para fundamentar essa decisão, tomaram-se como parâmetro as bases teóricas de Neil MacCormick (2009), o qual propôs, como meio de se aferir a correção das decisões judiciais, três requisitos: universabilidade, coerência e consistência. Assim, o método de MacCormick permitiu a classificação dos tipos de argumentos de que se valeram os ministros do Supremo Tribunal Federal, na fundamentação de seus votos, em três categorias: os linguísticos, os sistêmicos e os teleológicos/deontológicos.

II - empregar conceitos jurídicos indeterminados, sem explicar o motivo concreto de sua incidência no caso; III - invocar motivos que se prestariam a justificar qualquer outra decisão; IV - não enfrentar todos os argumentos deduzidos no processo capazes de, em tese, infirmar a conclusão adotada pelo julgador; IV - não enfrentar todos os argumentos deduzidos no processo capazes de, em tese, infirmar a conclusão adotada pelo julgador; V - se limitar a invocar precedente ou enunciado de súmula, sem identificar seus fundamentos determinantes nem demonstrar que o caso sob julgamento se ajusta àqueles fundamentos; VI - deixar de seguir enunciado de súmula, jurisprudência ou precedente invocado pela parte, sem demonstrar a existência de distinção no caso em julgamento ou a superação do entendimento" (BRASIL, 2015), evitando-se desta forma, a generalização dos precedentes e, em consequência, realizando um maior controle na sua aplicação.

Resenha Eleitoral (Florianópolis), v. 24, n. 1, p. 33-56, 2020 
Por conseguinte, como foi observado na análise dos votos, em especial o voto do ministro relator, Luís Roberto Barroso, observa-se, pelo menos parcialmente, uma inconsistência, pois ele indica que "não há, na Constituição de 1988, qualquer previsão expressa da 'regra da fidelidade partidária", e diz ainda que "o STF tradicionalmente considera que o artigo 55 contém rol taxativo de hipóteses de perda do mandato parlamentar, e, como se sabe, nele não se encontra a troca de partido por parlamentar". Mais adiante, contudo, ele afirma que "no sistema proporcional há fundamento constitucional consistente para a sua construção jurisprudencial; porém, no sistema majoritário não há". Dessa maneira, o voto, afinal, contradiz a norma de início citada. Além disso, o ministro relator não explica, em face dessa contradição, como a jurisprudência poderia ser construída. Parece, portanto, que ele apenas deseja justificar uma decisão anterior, a de 2007, quando do julgamento dos Mandados de Segurança nºs 26.602, 26.603 e 26.604, por meio do qual se alterou o entendimento do STF sobre o tema - entendimento esse que durava desde 1989.

A inconsistência também se fez presente no voto do ministro Ricardo Lewandowiski, uma vez que ele ressalta que "levar às últimas consequências a conclusão da Corte aplicada ao sistema proporcional levaria a criarmos uma nova hipótese de perda de mandato não prevista no art. 55 da Constituição", sem entrar, entretanto, no mérito de que o voto do Relator fala de "rol taxativo" das hipóteses de perda de mandato do art. 55, dentre as quais não aparece a infidelidade partidária. Ora, há que se frisar que o adjetivo "taxativo" é categórico, não admitindo nuances e gradações de sentido.

A despeito dessas inconsistências pontuais e internas no voto dos ministros, conclui-se que a decisão, por unanimidade, do Supremo Tribunal Federal, na Ação Direta Inconstitucionalidade nº 5081/2015, foi bem fundamentada, preenchendo os três requisitos (universabilidade, consistência e coerência) presentes na teoria de MacCormick, uma vez que o acórdão não reproduziu as inconsistências apontadas aqui, atendo-se ao fato de que a perda de mandato por infidelidade não deve ser aplicada aos cargos majoritários, pois isso traria drásticas consequências ao Estado Democrático de Direito, em face da violação do princípio democrático (art. 1², parágrafo único, CF) e da soberania popular (art. 14, caput, CF), ambos valores intrínsecos à ordem democrática de 1988. 


\section{Referências}

BONAVIDES, Paulo. Do país constitucional ao país neocolonial. 4. ed. São Paulo: Malheiros, 2009.

BRASIL. Código de Processo Civil. Lei no 13.105, de 16 de março de 2015. Das normas processuais civis. Das normas fundamentais e da aplicação das normas processuais. Disponível em: < http://www.planalto.gov.br/ccivil_03/_ Ato2015-2018/2015/Lei/L13105.htm>. Acesso em: 29 ago. 2020.

BRASIL. Constituição (1988). Constituição da República Federativa do Brasil. Diário Oficial da União, Brasília, DF: Senado Federal. Disponível em: $<$ http://www.planalto. gov. br/ccivil_03/constituicao/constituicao.htm>. Acesso em: 26 set. 2020.

BRASIL. Emenda Constitucional no 1, de 17 de outubro de 1969. Edita o novo texto da Constituição Federal de 24 de janeiro de 1967. Brasília, DF, 1969. Disponível em: < http://www.planalto.gov.br/ccivil_03/constituicao/emendas/emc_anterior1988/emc01-69.html>. Acesso em: 26 set. 2020.

BRASIL. Lei nº 9.096, de 19 de setembro de 1995. Dispõe sobre partidos políticos, regulamenta os arts. 17 e 14, $\int 3^{\circ}$, inciso V, da Constituição Federal. Diário Oficial da União, Brasília, DF: Senado Federal. Disponível em: < http://www2.camara.leg.br/ legin/fed/ lei/1995/lei-9096-19-setembro-1995-368874-norma-pl.html>. Acesso em: 11 ago. 2020.

BRASIL. Supremo Tribunal Federal. Ação Direta de Inconstitucionalidade no 1856/2011 - briga de galos (Lei fluminense oㅜ 2.895/98). Rel. ministro Celso de Mello. Julgamento em: 26 mai. 2011. Disponível em: < http:// redir.stf.jus.br/pagina dorpub/ paginador.jsp?docTP=AC\& docID=628 634> . Acesso em: 13 ago. 2020.

BRASIL. Supremo Tribunal Federal. Ação Direta de Inconstitucionalidade no 3999 DF e ADI n. 4086 DF. Rel. ministro Joaquim Barbosa. Julgamento em: 12 nov. 2008. Disponível em:<http:// redir.stf.jus.br/paginadorpub/paginador.jsp?docTP=AC\&docID=586946949>. Acesso em: 31 jul. 2020.

BRASIL. Supremo Tribunal Federal. Ação Direta de Inconstitucionalidade nº 5.081 Distrito Federal. Requerente: Procurador-Geral da República. Rel. ministro Roberto Barroso. Direito constitucional e eleitoral. Ação direta de inconstitucionalidade. Resolução n⿳0 22.610/2007 do TSE. Inaplicabilidade da regra de perda do mandato por infidelidade partidária ao sistema eleitoral majoritário. Julgamento em: 27 maio 2015. Disponível em: <http:/ / redir.stf.jus. $\mathrm{br} /$ paginadorpub/paginador.jsp?docTP $=\mathrm{TP} \& d o c I D=9175293>$. Acesso em: 28 jul. 2020. 
BRASIL. Supremo Tribunal Federal. Mandado de Segurança no ${ }^{0}$ 20927/DF - Distrito Federal. Mandado de Segurança. Fidelidade partidária. A inaplicabilidade do princípio da fidelidade partidária dos parlamentares empossados se estende no silêncio da constituição e da Lei, aos respectivos suplentes. Rel. ministro Moreira Alves. Julgamento em: 11 de outubro de 1989. Disponível em: $<$ http://redir.stf.jus.br/paginadorpub/paginador. jsp?docTP $=$ AC\&docID $=85369>$. Acesso em: 02 set. 2020.

BRASIL. Supremo Tribunal Federal. Mandado de Segurança no ${ }^{\mathbf{0}}$ 23405/GO - Goiás. Mandado de Segurança. Eleitoral. Possibilidade de perda de mandato parlamentar. Princípio da fidelidade partidária. Inaplicabilidade. Hipótese não colocada entre as causas de perda de mandato a que alude o art. 55 da Constituição. Rel. ministro Gilmar Mendes. Julgamento em: 22 de março de 2004. Disponível em: $<$ http:/ /redir.stf.jus.br/paginadorpub/ paginador. jsp?doc$\mathrm{TP}=\mathrm{AC} \& \operatorname{doc} \mathrm{ID}=85960>$. Acesso em: 02 set. 2020.

BRASIL. Supremo Tribunal Federal. Mandado de Segurança no 26602/ DF - Distrito Federal. Mandado de Segurança. O abandono de legenda enseja a extinção do mandato do parlamentar, ressalvadas situações específicas, tais como mudanças na ideologia do partido ou perseguições políticas, a serem definidas e apreciadas caso a caso pelo Tribunal Superior Eleitoral. Rel. ministro Eros Grau. Julgamento em: 04 out. 2007. 2007a. Disponível em: < http:/ / redir. stf.jus.br/paginadorpub/paginador.jsp?docTP $=$ AC\&docID $=555539>$. Acesso em: 02 set. 2020.

BRASIL. Supremo Tribunal Federal. Mandado de Segurança no 26603/ $^{-26}$ DF- Distrito Federal. Mandado de Segurança. A subsistência dos atos administrativos e legislativos praticados pelos parlamentares infiéis: consequência da aplicação da teoria da investidura aparente- o papel do Supremo Tribunal. Rel. ministro Celso de Mello. Julgamento em 04 out. 2007. 2007b. Disponível em: $<$ http://redir.stf.jus.br/paginadorpub/paginador.jsp?docTP $=$ AC\&docID $=570121>$. Acesso em: 02 set. 2020.

BRASIL. Supremo Tribunal Federal. Mandado de Segurança no 26604/ DFDistrito Federal. Mandado de Segurança. Direito Constitucional e Eleitoral. Natureza jurídica e efeitos da decisão do Tribunal Superior Eleitoral- TSE na consulta 1.398/2007. Natureza e titularidade do Mandato Legislativo. Os partidos políticos e os eleitos no sistema representativo proporcional. Fidelidade partidária. Efeitos da desfiliação pelo eleito: perda do direito de continuar a exercer o Mandato Eletivo. Rel. ministra Cármen Lúcia. Julgamento em: 04 out. 2007. 2007c. Disponível em: <http://redir.stf.jus.br/paginadorpub/paginador. jsp?docTP=AC\&docID=552057>. Acesso em: 02 set. 2020. 
BRASIL. Tribunal Superior Eleitoral. Resolução no $\mathbf{2 2 . 6 1 0}$, de 25 de outubro de 2007. O Tribunal Superior Eleitoral, no uso das atribuições que lhe confere o art. 23, XVIII, do Código Eleitoral, e na observância do que decidiu o Supremo Tribunal Federal nos Mandados de Segurança n⿳⺈ 26.602, 26.603 e 26.604, resolve disciplinar o processo de perda de cargo eletivo, bem como de justificação de desfiliação partidária. Disponível em: < http:/ /www.tse.jus.br/ legislacao-tse/res/2007/RES226102007.htm>. Acesso em: 02 set. 2020.

BRASIL. Tribunal Superior Eleitoral. Consulta 1.398 - Brasília- DF. Resolução no 22526 de 27/03/2007. Consulta. Eleições proporcionais. Candidato eleito. Cancelamento de filiação. Transferência de partido. Vaga. Agremiação. Resposta afirmativa. O Tribunal, por maioria, respondeu positivamente à Consulta, na forma do voto do relator. Julgamento em: 8 maio 2007. Disponível em: $<$ http://www.tse.jus.br/jurisprudencia/decisoes/jurisprudencia>. Acesso em: 02 set. 2020.

CHAMON JUNIOR, Lúcio Antônio. Teoria da argumentação jurídica: Constitucionalismo e democracia em uma reconstrução das fontes do Direito Moderno. 2. ed. Rio de Janeiro: Lumen Juris, 2009.

COTTA, Maurizio. Dicionário de Política. 13. ed. Brasília: UnB, 2010. v. 2, p. 1105.

LEITE, Cassio Prudente Vieira. Transfuguismo partidário e representação política. In: SALGADO, Eneida Desiree; DANTAS, Ivo (Coord.). Partidos políticos e seu regime jurídico. Curitiba: Juruá, 2013.

LOPES, Ana Maria D’Avila; BENÍCIO, Márcio. Análise da decisão judicial sobre a "briga de galos" (Adin no 1. 856/2011) a partir da teoria argumentativa de Neil MacCormick. Revista Brasileira de Direito Animal, Salvador, v. 10, n. 20, p. 37-58, 2015.

MACCORMICK, Neil. Argumentação jurídica e teoria do Direito. Trad. Waldéa Barcellos. 2. ed. São Paulo: Martins Fontes, 2009.

MACCORMICK, Neil. Retórica e o Estado de Direito. Trad. Conrado Hübner Mendes. Rio de Janeiro: Elsevier, 2008.

MACCORMICK, Neil. Argumentación e interpretación em el derecho. DOXA Cuadernos de Filosofía del Derecho, Alicante, Espanha, v. 33, p. 65-78, 2011.

MARINONI, Luiz Guilherme. Precedentes Obrigatórios. 3. ed. São Paulo: Revista dos Tribunais, 2013. 
MARTINS, Argemiro Cardoso Moreira; ROESLER, Claudia Rosane; JESUS, Ricardo Antonio Resende de. Revista NEJ - Eletrônica, v. 16, n. 2, p. $207-$ 221, maio/ago., 2011.

MEZZAROBA, Orides. Partidos políticos. Curitiba: Juruá, 2010.

MORAES, Filomeno. Participação e representação na ordem constitucional brasileira: continuidades e descontinuidades. In: MORAES, Filomeno; SALGADO, Eneida Desiree; AIETA, Vânia Siciliano. (Org.). Justiça Eleitoral, controle de eleições e soberania popular. 1 ed. Curitiba, 2016, v. 1, p. 183 211.

PEIXOTO, Fabiano Hartmann; ROESLER, Claudia Rosane; BONAT, Debora. Decidir e argumentar: racionalidade discursiva e a função central do argumento. Revista da Faculdade de Direito - UFPR, Curitiba, v. 61, n.3, p. 213 - 231, set./dez. 2016.

RUBINGER-BET'TI, Gabriel; ROESLER, Claudia. As limitações e possibilidades dos critérios avaliativos propostos por Neil MacCormick para a argumentação jurídica. Revista de Direitos e Garantias Fundamentais, Vitória, v.18, n. 1, p. 133-164, jan./abr. 2017.

SALGADO, Eneida Desiree. Princípios constitucionais eleitorais. 2. ed. Belo Horizonte: Fórum, 2015.

SUMMERS, Robert S. Two Types of Substantive Reasons: The Core of a Theory of Common-Law Justification (1978). Cornell Law Faculty Publications. Paper 1194. Disponível em: <http://scholarship.law.cornell.edu/ facpub/1194>. Acesso em: 29 ago. 2020.

Katarina Karol Brazil de Melo Rocha - Mestra em Direito Constitucional pela Universidade de Fortaleza - UNIFOR. Especialista em Direito Constitucional pela ESMEC. Especialista em Marketing Político e Campanhas Eleitorais pela PUC/SP. Advogada. E-mail: katarinabrazil.adv@gmail.com.

José Filomeno de Moraes Filho - Professor (aposentado) da Universidade Estadual do Ceará. Doutor em Direito pela Universidade de São Paulo. Livre-docente em Ciência Política pela Universidade Estadual do Ceará. Parecerista. E-mail: filomenomoraes@uol.com.br. 